\title{
Reconnoitring the Effectiveness use of "Double Bubble Map" in Learning Jawi Script among Pupils in Malaysian Primary Schools
}

\author{
Muhamad Zahiri Awang Mat ${ }^{1}$ \\ Siti Salwa Md. Sawari² \\ Salina Mohd Rasul ${ }^{3}$ \\ Nazariyah Saad 4 \\ Kasmah Jusoh 5 \\ 1,3,4,5 Kulliyah of Education, International Islamic University Malaysia \\ 2Faculty of Islamic Civilization, Universiti Teknologi Malaysia; Email: 'zahiri@iium.edu.my
}

\section{Doi:10.5901/mjss.2016.v7n2s1p425}

\section{Abstract}

The effectiveness of a teaching process will be determined by various factors. Among the most influences factor is methods use within teaching process. The objective of this study is to explore the effectiveness uses of "double bubble map" method in improving students' skills to recognize prefix and root words. In this study, a mixmode research design was used. In order to discover this objective researcher used test and observation as an approach to discover the objective. A sample of eight pupils of primary schools located in Malaysia was selected. With targeted of pupils with low level of Jawi proficiency. Based on the data analysis, there is a significant increase in pupils' scores in tests conducted after the intervention. In addition, the observations made to the respondents showed that pupils understand how to recognize prefix words and root words besides the use of "double bubble map" method which enticed pupils' interests and attention in learning. Therefore, it can be concluded that the use of "double bubble map" method in prefix learning lessons has been successful and improved the pupils' proficiency in recognizing prefix words.

Keywords: Double Bubble map; Prefix Word; Root Word.

\section{Introduction}

Islamic education is a compulsory subject for all students after the national independence and the introduction of formal educational system. The alteration of Integrated Curriculum for Primary Schools (KBSR) to the Standard Curriculum for Primary Schools (KSSR) has given new appearances to the Islamic education in terms of systematic teaching session, more structured syllabus and so on (Azlina, Norazura Ezuana, Siti Salwa, 2013). In fact, the development of this subject is in line with the government's new policy in education. Currently, the Ministry of Education (2013) through the Education Development Plan 2013-2025 outlines 11 major shift that strengthen the Islamic and Moral Education by giving more emphasis on unity and promoting understanding among students.

Standard Curriculum of Islamic Education for Primary School has been introduced to meet the needs of Islamic education in a holistic and integrated way in accordance with the requirements of the National Education Philosophy and Islamic Education Philosophy. This curriculum covers seven modules which is the Qur'an, Hadith, Faith, Worship, Sirah of the Prophets, Ethics and Jawi. The objective of Standard Curriculum for Primary Schools (KSSR) Islamic Education is that the students can read and write in Jawi script and love it as the nation's cultural heritage.

Based on the observation, the Jawi proficiency level among primary school pupils is worrisome (Siti Salwa, Muhammad Zahiri, 2013), especially in terms of writing (Muhamad Zahiri, Siti Salwa, Zarqo' \& Siti Zuraidah, 2015). There are many methods and techniques that have been used over time to increase the pupils' proficiency level in Jawi lessons. Nuriati Abdullah and Norhannan Ramli (2012) have stated that the Jawi writing skills definitely need training and guidance in order to produce students who are capable to produce perfect form of writing using sensory and mental capabilities. Therefore, teachers are responsible for making Jawi lessons as something easy to understand and remember. 


\subsection{Research Objectives}

1. Does the "double bubble map" method improves student skills to recognize prefix and root words?

2. Can the "double bubble map" method improves the effectiveness in identifying the prefix and root words?

\section{Literature Review}

\subsection{Mind Mapping}

Teaching is essential in any field of study. The effectiveness of a teaching process will be determined by many factors, one of those through the methods use within it. Nowadays, there are so many methods ensuring the process of teaching which can maximize the students' understanding. A teaching method like a backbone to the whole process of teaching, so the method chooses undeniably important. In the teaching sphere, language is one of the priority subjects at school and even at the higher level of education, the proficiency of language becomes a requirement for admission. Mind mapping is one of the methods which believed crucial to ensure the effectiveness of teaching language.

Riswanto and Purta (2012) study of writing by using mind mapping, since writing part of the language element, their study indirectly emphasizes on the relation between mind mapping and language subject. Suyanto (2010) study about the effectiveness of mind mapping to teach writing skill viewed from their IQ which shown the significant link between mind mapping and teaching language (writing skill). Their study indicates that mind mapping and teaching language are a good combination and looked more details into different dimensions. A good method or medium for remembering, creative intellect, and learning has confirmed by the use of mind mapping (Gómez \& King, 2014). Another study focused on writing skill (part of the language) study by Imran, Shahriar and Md. Jahidur (2011) which is a mind map for academic writing, al-Naqbi (2011) on the use of mind mapping in order to develop writing in UAE and Nemati, Jahandar and Khodabandehlou (2014) about the effect of mind mapping on essay writing in Iran. Wai Ling (2004) study on the effectiveness of using mind mapping skills in enhancing secondary one and secondary four students' writing in a CMI School, enhancing freshman students' writing skills with a mind mapping software and incorporating mind mapping into the teaching of comprehension skills enhances students' understanding and memory of comprehension passages (Wong-Ang, Gek Moi and Ong Lee Lian, 2007).

Siriphanich and Laohawiriyanon (2010) and Rizqiya (2013) study about mind mapping technique at Thailand and Indonesia to improve reading comprehension ability which is part of the teaching language process. There are other studies which show the connection between teaching language and mind mapping, which are using mind maps to raise standards in literacy, improve confidence and encourage positive attitudes towards learning by Cain (2001/2002). Moreover, there are study even focus on teaching spelling skills with a mind mapping software (Al-Jarf, 2011).

In addition, Sujana (2012) integrate mind mapping method in teaching academic reading in English language, this study quite different to the previous one since it focuses directly on a specific language. Besides, there are studies which focus on foreign language by using mind mapping (Ariana \& Mirabela, 2012) and (Casco, 2009) but in a different field of study. Writing, reading, spelling and direct dealing with certain language are elements which form the language subject, or course, so all those skills obviously related to the study. Since mind mapping is important, the invention of mind mapping in the form of software had been introduced as being studied by T Tungprapa (2015) about electronic mind maps and creating online mind map (Douma, Ligierko \& Romano (2009).

\subsection{Double Bubble Map}

In teaching process, mapping is one of the means in teacher's strategies (Riswanto \& Putra, 2012). This method able to encourage and motivated students in learning and thinking (Siriphanich \& Laohawiriyanon, 2010). "It helps students to assimilate new information, to think and to develop their conceptual schema" (Keleş, 2012). Gómez and King (2014) study on using mind mapping as a method to help ESL/EFL students connect vocabulary and concepts in different contexts. There are various type of mind mapping that has been used in learning, one of the most effective is Double Bubble Map. This type of mapping used circle as the part of presentations in the mind mapping. Each circle was used to explain different point of explanations. Figure 1 shows the example of Double Bubble Map: 


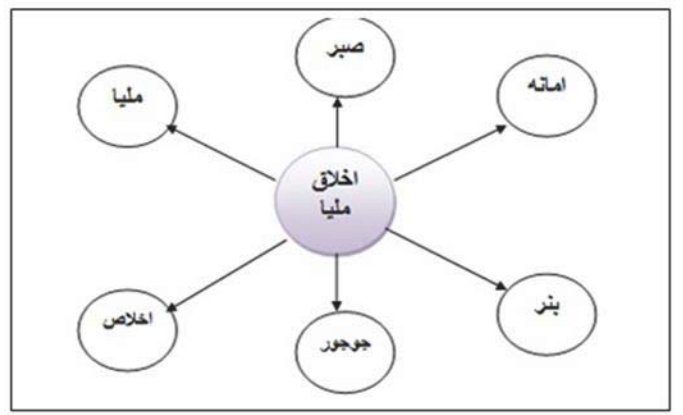

Figure 1: Double Bubble Map.

\subsection{Jawi Script}

Jawi script has been established in Malay world since 1300 AD. The writing of Jawi confined to religious and cultural use. Developments related to the arrival of Islam, especially from the Persians. The Arabic alphabet was introduced modified to conform to the classical Malay language spoken. Jawi script is written from right to left, and supplemented with 6 letters not in Arabic, ie ca pa nga ga va and her (John, 1988). Previously, Jawi script has been acknowledge as official writing system in Malaysia. However, now it serve as an alternative writing system in Malaysia. In terms of usage, Jawi script has been replaced by Roman script.

According to Musa, Aziz \& Yasran (2009), currently Rumi script has dominated the Malay language writing. It occur since 1963 when Rumi has been declared as the official written language of Malay, and thus marginalize the Jawi script. Jawi writing is no longer a matter of education in the school, except for a handful of students in specific schools and learning Islamic studies subject. The limitations in used of Jawi script has created negative circumstance when people start to forget this scripture.

\section{Research Methodology}

Acording to Ragin (2010), research design can be defined as a plan for collecting and analysing evidences that could help the investigator to answer the questions he or she poses. There are three types of research designs depending on the mode of inquiry, namely qualitative, quantitative, and mixed mode. In this study, a mixmode research design was used. The research aimed to explore the effectiveness uses of "double bubble map" method in improving students' skills to recognize prefix and root words. In order to discover this objective researcher used test and observation as an approach to discover the objective.

\subsection{Sample}

A sample of eight pupils of primary schools located in Malaysia was selected. With targeted pupils of four male and four female. All the target group consists of pupils with low level of Jawi proficiency.

\subsection{Test}

Written tests were carried out to the target group to investigate their understanding on the prefix and root words. The participants' efficiency in identifying and distinguishing prefix words and root words were also being tested. After reviewing the test papers, it has been found that there were still pupils who made errors not because their lack of understanding about the learning lessons but it was because of their less proficiency in reading Jawi script.

\subsection{Observation}

The observation of this study involved an interaction between researchers and students. Researchers have looked at the impact of countervailing undertaken by students. In this process, researchers have considered the pupils to be observed 
as subjects and they have interacted with each other. The results of this observation have developed the research data. Thus, the researchers will indirectly "be involved in conducting the observation (participatory observation) to understand the issues related to the object of study, particularly in relation to the general state of the research location and other symptoms developed in the study area" (Mustaffa, Ghazali, Sawari, 2015).

\subsection{Activities}

In carrying out the study, the researchers have done three different activities.

1. Identify prefix words and root words.

2. Classify prefix words and root words using the "double bubble map" method.

3. Written tests through worksheets to test the effectiveness of the "double bubble map" method.

\subsubsection{Activity 1}

Identify prefix words and root words.

The participants did group activities through finding and reading bubble flash cards that contained prefix words and root words and they pasted the words to the appropriate place by using the "double bubble map" method. Teachers have introduced the "double bubble map" method to the pupils. The prefix words have been taught in the classroom by using explanation. The teacher have done some improvements in teaching and learning sessions by using teaching aids such as bubble flash cards. The bubble flash cards explanation method is using large models until pupils understand its usage. The teachers gave examples of prefix like "سفو هون" with examples of word with prefix like "سف " and examples of word from the root word "سندوق". Besides that, pupils were asked to pronounce prefix, prefix words, and root words that have been shown. Apart from that, pupils were asked to give other examples of prefix, prefix words and root words. They were asked to paste the bubble flash cards in the appropriate place as describe in figure 2 :

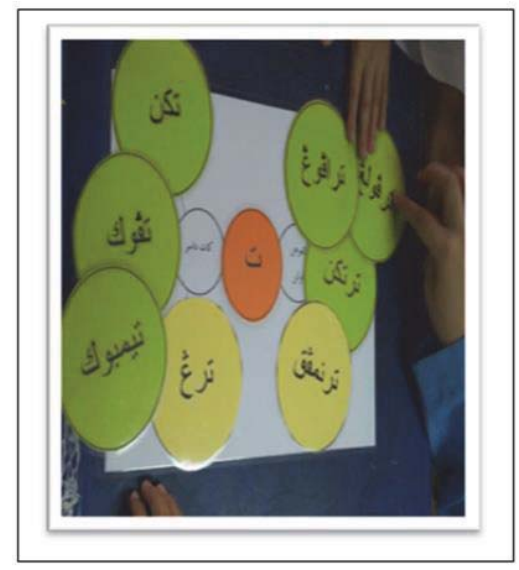

Figure 2: Exercises with bubble flash cards

The teachers asked the pupils to sit in pairs. Every pair of pupils were required to take a set of bubble flash cards provided. One set consists of a bubble flash card contains letter, three bubble flash cards contain prefix and three bubble flash cards contain root words. The bubble flash cards given to pupils were in a smaller form. Teachers also distributed a "double bubble map" card to each group of pupils. The teachers asked the pupils to pronounce what they have got from the flash cards. The pupils pasted the bubble flash cards on the "double bubble map" that they have without their teachers' assistance.

Teachers only observed the pupils' assignments. The pupils were asked to read out their works one by one in group. The pairs then pasted their assignments in the classroom's white board. The pupils were asked to read their assignments in front of the classroom. The teachers asked the students to rewrite the assignments into their exercise books. 


\subsubsection{Activity 2}

Classify prefix words and root words using the "double bubble map" method.

Pupils read the text during teaching and learning session in classroom, individual and group. Pupils were asked to pronounce, come up with prefix words that were in the text and give some other examples by using the "double bubble map" method to find a comparison. Then, pupils were given reading materials. Teachers have used short stories as stimulus. Pupils were required to read the story from the reading materials individually and in the classroom.

Information and Questions \& Answers related to the passage being read.

After this process, pupils were asked to circle the words of Jawi script that begin with letters first paragraph only. The teachers have linked the "double bubble map" method that has been learned in the previous weeks and have given some examples.

Questions and answers related to the difference between prefix words and root words.

The teachers have distributed a sheet of "double bubble map" to each pupils. The teachers have tested the pupils' ability to recognize prefix words and root words by classifying the words that were circled using the "double bubble map" method. Pupils only have to fill in the five prefix words and five root words. Discussions were made regarding the activities. Pupils continued making their tasks with the second paragraph and so on. They were asked to choose and write prefix words and root words in their workbook by using the "double bubble map" method.

\subsubsection{Activity 3}

Written tests using the worksheets have been done to test the effectiveness of the "double bubble map" method. The worksheets were used to test the pupils' understanding and effectiveness of using the "double bubble map" method of

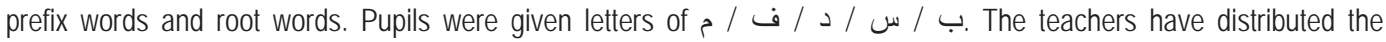
worksheets as a written test. The test questions consisted of 3 phases which were reading and underlining prefix words and root words through understanding the sentence. In the second phase, the pupils were required to choose and write prefix words and root words in the "double bubble map" while in the third phase, pupils were required to make prefix words and root words into Jawi script to test their writing. The tests were reviewed and evaluated to get the final data.

\section{Findings and Discussion}

Identify prefix words and root words.

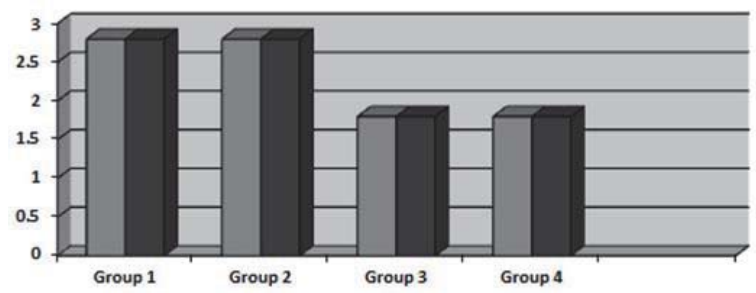

Figure 2: Proficiency in recognizing prefix words and root words

Figure 2 shows the results of the pupils' assignments to evaluate their proficiency in recognizing prefix words and root words using the "double bubble map" method. Based on Figure 1, it has been found that overall; the pupils got good marks after carrying out the intervention. Scores were given based on the pupils' correct and accurate answers. The number of words provided in the activity 1 consist of 3 prefix words and 3 root words that representing 3 marks per category.

Classify prefix words and root words using the "double bubble map" method. 


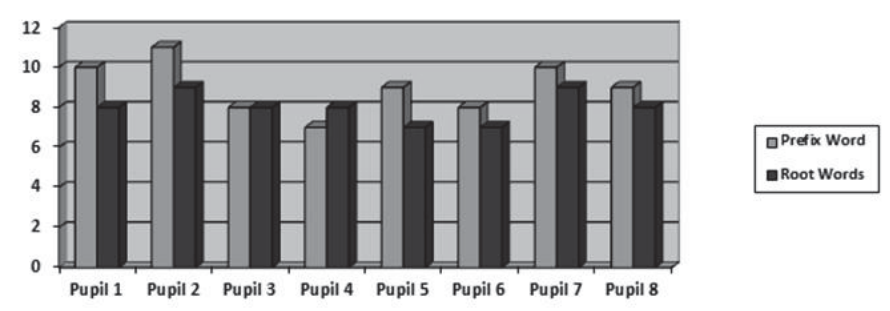

Figure 4: The pupils' proficiency in identifying and classifying prefix words and root words

Figure 4 shows the results gathered from the worksheets to evaluate the pupils' proficiency in identifying and classifying prefix words and root words using "double bubble map" method.

Overall, the pupils' scores improved for both schools. The scores were based on the total number of correct answers answered by the pupils. The number of words contained in the first paragraph was 12 prefix words and 12 root words. The pupils were required to choose only 10 answers from both categories.

\section{Analysis of the findings of activity 3}

Written tests through worksheets to test the effectiveness of the "double bubble map" method.

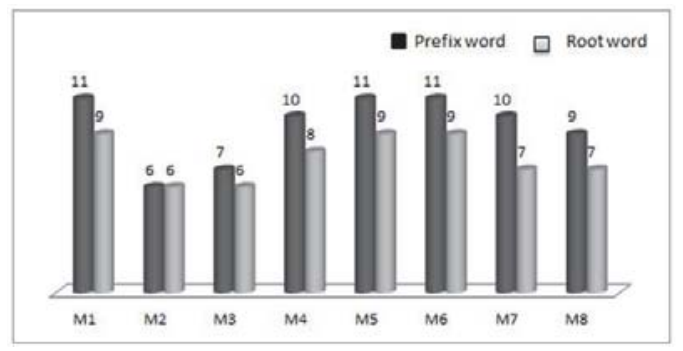

Figure 5: Result effectiveness of the "double bubble map" method and the pupils' proficiency in identifying prefix words and root words

Figure 5 shows the results of the worksheets to evaluate the effectiveness of the "double bubble map" method and the pupils' proficiency in identifying prefix words and root words, besides evaluating the effectiveness of teaching method. Based on figures 3 and 4, it has been found that there is a change and increase in pupils' scores after the intervention. The scores were based on the total number of correct answers answered by the pupils.

What Can the "double bubble map" method improve the effectiveness in identifying prefix words and root words?

\subsection{Interest}

During the intervention, it seemed that the pupils were interested in the "double bubble map" method especially when they were put in pairs. This approach was more robust, the pupils were more focussed and paying attention to the teachers.

\subsection{Focus}

This was proven through the pupils' full attention towards their teachers during learning lessons.

Sometimes, the pupils asked questions which showed that they were paying attention during learning session and they required teacher's certainty regarding the lesson.

Based on the observations, the pupils have focused on their learning through the "double bubble map" method and felt that the method used was interesting. 


\subsection{Understanding}

In terms of pupils' understanding, it could be seen that there has been increased in understanding and proficiency on how to recognize prefix words and root words. This has been proven by observations where the pupils could choose and paste the right prefix and root words. In addition, they seemed to be faster in completing tasks and provide the correct answers.

The pupils could understand and recognize prefix words and root words correctly although there were some of them who were weak in reading the Jawi script. The pupils' acceptance were more clear with the "double bubble map" method. Pupils were able to differentiate prefix words and root words when they were given the sentences. I will use this method again to be implemented in activity 3 to see how effective it is in teaching and learning session.

\subsection{Motivation}

The use of "double bubble map" method in teaching and learning Jawi script is indirectly improving students' reading proficiency in sentence form. This is because a proper understanding of the method of recognizing prefix words and root words can help the students.

\section{Conclusion}

Based on the data analysis, there is a significant increase in pupils' scores in tests conducted after the intervention. In addition, the observations made to the respondents showed that pupils understand how to recognize prefix words and root words besides the use of "double bubble map" method which enticed pupils' interests and attention in learning . Therefore, it can be concluded that the use of "double bubble map" method in prefix learning lessons has been successful and improved the pupils' proficiency in recognizing prefix words. Besides that, there has been an increase in teachers' practice for teaching prefix. Based on the findings, the teachers must teach in ways that are easily understood and remembered by their students. Moreover, the teaching methods must be able to attract pupils' interests towards learning so that no information is leaking which can affect the Jawi lesson negatively. The results showed that the students could be assisted to have pleasant experiences during teaching and learning sessions.

\section{References}

Nemati, A., Jahandar, S., \& Khodabandehlou, M. (2014). The effect of mind mapping technique on the enhancement of advanced Iranian EFL learners' essay writing ability through organizing information and thoughts. Indian Journal of Fundamental and Applied Life Sciences, 4(1), 96-104.

Casco, M. (2009). The use of mind maps in the teaching of foreign languages. Unpublished Article.

Al-Naqbi, S. (2011). The use of mind mapping to develop writing skills in UAE schools. Education, Business and Society: Contemporary Middle Eastern, 4(2), 120-133. doi: http://dx.doi.org/10.1108/17537981111143855

Al-Jarf, R. (2011). Teaching spelling skills with a mind mapping software. Asian EFL Journal Professional Teaching articles, 53, 4-16.

Imran, M., Shahriar, R., \& Md. Jahidur, Rahman. (2011). Mind map for academic writing: a tool to facilitate university level student. International Journal of Educational Science and Research, 1(1), 21-30.

Gómez, M. I., \& King, G. (2014). Using mind mapping as a method to help ESL/EFL students connect vocabulary and concepts in different contexts. TRILOGÍA. Ciencia, Tecnología y Sociedad, 10, 69-85.

Siriphanich, P., \& Laohawiriyanon, C. (2010). Using mind mapping technique to improve reading comprehension ability of Thai EFL university students, the 2nd International Conference on Humanities and Social Sciences, 1-13. url: http://tar.thailis.or.th/ bitstream/123456789/892/1/001.pdf

Riswanto., \& Putra, P. P. (2012). The use of mind mapping strategy in the teaching of writing at SMAN 3 Bengkulu, Indonesia. International Journal of Humanities and Social Science, 2(21), 60-68.

T Tungprapa. (2015). Effect of using the electronic mind map in the educational research methodology course for Master-degree students in the faculty of education. International Journal of Information and Education Technology, 5(11), 803-807. doi: 10.7763/IJIET.2015.V5.615

Douma, M., Ligierko, G. \& Romano, J. (2009). Creating online mind maps and concept maps. $25^{\text {th }}$ Annual Conference on Distance Teaching and Learning. 1-8. url: http://www.uwex.edu/disted/conference.

Keleş, Ö. (2012). Elementary teacher's view on mind mapping. International Journal of Education, 4(1), 93-100. doi:10.5296/ije.v4i1.13 27

Ragin, (2010). Constructing Social Research. The Unity and Diversity of Method. Retrieved 11/7/2013 from http://uwhonors2010.virtual knowledgestudio-.nl/wp-content/uploads/reading/Ragin.pdf

Suyanto, A. (2010). The effectiveness of mind mapping to teach writing skill viewed from their IQ. (Graduate degree dissertation, 
Sebelas Maret University, 2010). Retrieved from http://core.ac.uk/download/pdf/12351795.pdf

John U. W. (1988). Indonesian Readings Edition: 3, SEAP Publications

Musa, H., Aziz, A., \& Yasran, A. (2009). Empowerment back Jawi. Jurnal ASWARA, 4(1), 159-176.

Curriculum Development Division. (2012). Standard Document Standard Curriculum for Primary Schools (KSSR) Islamic Education Year 3. Putrajaya: Ministry of Education

Kementerian Pendidikan Malaysia. (2013). Malaysia Education Blueprint 2013-2025. Putrajaya, Malaysia: Ministry of Education.

Rizqiya, R. S. (2013). The use of mind mapping in teaching reading comprehension. ELTIN Journal, 1(1), 32-43.

Sujana, I. M. (2012). Integrating a mind mapping technique and information gap activities in teaching academic reading in English. English for Specific Purposes World, 36(12), 1-19.

Siti Salwa Md. Sawari, Muhammad Zahiri Awang Mat, Mohd Al'Ikhsan Ghazali. (2014). Nurturing The Enthusiasm and Ideals of Teachers Through Reflective Ibnu Jama'ah's Book: Tazkarat As-Same Wa Al-Mutakillim Fil Adab Al-Alim Wa Al-Muta'allim. . 5th International Graduate Conference on Engineering Science \& Humanity 2014. 21st -22nd August 2014. ISSN 1823-3287.

Siti Salwa Md. Sawari, Muhammad Zahiri Awang Mat. (2013). Harmonizing Al Qabisy's View And Practice Of j-Qaf Programme In Malaysian Primary School. Asian Journal Education Management and Science 2(11):

Azlina Mustaffa, Norazura Ezuana Bte Najid, Siti Salwa Md. Sawari, (2013). Students' Perceptions and Attitude towards the effectiveness of Prezi Uses in learning Islamic Subject. International Journal of Advanced Studies in Computer Science and Engineering (IJASCSE), 2 (6): 51-57. 5 January 2014. 